subjects on whom the observations were made. The work of linking up machine-made hosiery is very fine, the operators requiring to be from five to eight inches from the machine, and, since nearly 80 per cent. of the factory work consists of linking, it is obvious that a very prolonged accommodative effort is required. The lighting conditions were tested first and found to be adequate. The output of three operatives (two experienced and one learner) was recorded for a period of four weeks in order to determine the normal rate of work under existing conditions. The operatives were then examined and fitted with suitable glasses, and their output recorded during a second period of four weeks. Charts and photographs accompany this part of the report. As a result it was found that for each subject a considerable increase in the rate of working accompanied by a reduction of fatigue was effected as a result of the use of glasses. Further, after the conclusion of the experiments the subjects continued to wear the glasses. Mr. Laws states in the appendix that the subjects were allowed to choose the sphere, which added to their estimated refraction gave them the sharpest vision at the desired distance. This varied from $0.75 \mathrm{D}$. to $1.75 \mathrm{D}$. No effort was made to aid convergence with a prism, though the authors suggest that this might be of even further use.

These reports of the Medical Research Council are of very great value and we trust that they will find a wider circulation than most Government publications.

\title{
Judicial Blinding
}

Perhaps the above title is not the best that could be chosen, since few of those who suffered mutilation by having their eyes put out in early times, probably, had any chance of a judicial hearing as we should conceive it nowadays, before the sentence was carried into execution. We do not pretend to know much about the history of the laws of the realm, but we doubt whether blinding was much used as a penalty after the days of Glanvill (1180). There can, however, be no doubt that it was frequently performed before that date. Common sense must have convinced people that a blinded man might just as well be dead and not be a tax on the community or any member of it.

Among the statutes of the Conqueror, given by Stubbs in "Select Charters" is the following: "Interdicto etiam ne quis occidatur aut suspendatur pro aliqua culpa, sed eruantur oculi, et testiculi abscidantur. Et hoc praeceptum non est violatum super forisfacturam meam plenam." 
The details of an early example of blinding are narrated by Freeman in the "History of the Norman Conquest," Vol. I, pp. $545-550$, and may be of interest to our readers :

"On the death of Cnut in 1036 the Aethelings Eadward, afterwards the Confessor, and his younger brother, Aelfred, the sons of Aethelred the Unready, i.e., lacking rede or counsel, and Emma his wife, made an attempt to recover the English kingdom. The chronicles of the time are exceedingly indefinite, and it does not seem clear how great a part Eadward took in the enterprise; he is said to have landed at Southampton, to have won a skirmish, and to have decamped with his plunder. His brother's attempt is better recorded. Soon after Eadward's return, Aelfred landed at Dover, was received by Godwine 'freondlice,' friendly, and it is recorded that he supped at Guildford. During the night he was taken prisoner and sent to Cnut's son, Harold, the King of England. Harold is said to have blinded the Aetheling and to have sent him to Ely, naked, with his legs tied under his horse's belly. At Ely he died, as the weapon with which his eyes had been cut out had wounded the brain. 'cui dum oculi effoderentur cultro cerebrum violavit mucro.',"

In this very early example of excision we may assume either that the executioner must have been extremely clumsy or more probably that the wounds were infected and that the unfortunate Aetheling died from the results of an extension of infection backwards to the meninges and brain.

A later example of what we have called judicial blinding took place at the siege of Exeter by the Conqueror in 1067. The same story is told of the siege of Oxford.

Before ordering an assault on the defences of the city William had the eyes of one of those who had been sent to him as hostages put out in the presence of the two forces. This would seem to be stretching the rules of warfare to an unwarrantable limit, but the Conqueror had his reasons. William of Malmesbury, Gesta Regum Anglorum, lib. 3, section 248, gives these as follows: "quia unus eorum, supra murum stans, nudato inguine auras sonitu inferioris partis turbaverat, pro contemptu videlicet Normannorum."

Of a truth William lived up to his reputation recorded by Robert of Gloucester :

"To hem that wolde his wylle do, debonere he was and mylde,

And to hem that hym wothseyde stark tyrant and wylde."

We cannot help feeling that he was unnecessarily stark in this instance; he should have sworn by the splendour of God to have so treated the contemptuous culprit, when he had caught him, and not one sent as a hostage. Under his son, Henry the First, the art of judicial blinding seems to have reached its acme. 